\title{
Estimates of Genetic Variability, Correlation and Path Analysis in Sunflower (Helianthus annuus L.)
}

\author{
M. S. Hassan, F. Sh. Sedeck* and Sahar A. Farag ${ }^{* *}$ \\ Agronomy Department, Faculty of Agriculture, South Valley \\ University, Qena; ${ }^{*}$ Oil Crops Res. Dept., Field Crops Research \\ Institute and ${ }^{* *}$ Central Lab. for Design \& Statistical Analysis \\ Research, ARC, Giza, Egypt.
}

\begin{abstract}
7 WELVE sunflower genotypes were evaluated for two years; 2013 and 2014 at three locations; Agricultural Research Stations of Shandaweel (location 1), Al-Arish (location 2) and El-Ewyinat east (location 3). Genotypic and phenotypic variances, their coefficient of variation, heritability and genetic advance were assessed. As well as study the interrelationships among oil yield attributers using genotypic and phenotypic correlation and path coefficients analysis were done. The experiments were conducted in a randomized complete block design with three replications in the field. Results proved that significant differences were observed among sunflower genotypes, for all studied characters in the three locations over two seasons. The elite genotype No 7 (Line120) surpassed the two check cultivar (Sakha 53 and Giza 102) recording the maximum values of seed yield in the first location with produced the maximum values in the second location for head diameter and seed yield and recording the maximum values of head diameter, seed yield and oil yield in the third location.
\end{abstract}

Estimates of heritability in broad sense at the three locations were varied from; $26-97 \%, 29-96 \%$ and 57-97\%, respectively. Results also indicated that, highly significant and positive correlation coefficients were obtained between oil yield and some studied traits at the genotypic and phenotypic levels in the three locations. According to path coefficients analysis (at genotypic and phenotypic levels), the traits, i.e. days to $50 \%$ flowering and plant height in location 1, days to $50 \%$ flowering, plant height, head diameter and 100 -seed weight in location 2 and 100-seed weight and seed yield/plant in location 3 were important predictors of oil yield indicating their magnitude as selection criteria to obtain a valuable gain of selection for oil yield in sunflower.

Keywords: Sunflower, Genetic parameters, Genotypic and phenotypic correlation coefficients, Path coefficients analysis, Oil yield components.

Sunflower (Helianthus annuus L.) is considered one of the most important edible oilseed crops after soybean and palm in the world. Its seeds contain a high content of a good quality oil, i.e. $40-50 \%$ and $20 \%$ of protein. Sunflower 
breeders focus all their interest in the development of sunflower genotypes with the maximum seed and oil yields. The variability of initial materials playing the major role in the success of any breeding program (Fick \& Miller, 1997 and Vranceanu, 2000). Oil yield as a polygenic trait is influenced by several characters called oil yield contributing traits. These components are related among themselves and with oil yield either positively or negatively. Correlation analysis does not provide the clear picture of complex associations among the plant traits. Path coefficient analysis is considered as a more precise method to dividing the direct and indirect influences of independent variables upon the dependent variable. In this respect, the association between oil yield and some other attributers using correlation and path analysis was studied by Fick et al. (1974), Skoric (1974), Green (1980), Marinkovic (1992), Punnia \& Gill (1994), El-Hosary et al. (1999), Farhatullah \& Khalil (2006), Habib et al. (2007), Hlandi et al. (2010), Hassan et al. (2013) and Kang \& Ahmed (2014).

The objectives of this research work were study the variations among the evaluated genotypes through estimates of genotypic and phenotypic variances $(\mathrm{Vg}$ and $\mathrm{Vph}$ ), genotypic and phenotypic coefficient of variation (GCV and PCV), broad sense heritability and genetic advance as well as understanding the interrelationships among oil yield attributers via study the genotypic and phenotypic correlation and path coefficients analysis.

\section{Materials and Methods}

The present work was performed at the three locations; Agricultural Research Stations of Shandaweel (location 1), Al-Arish (location 2) and El-Ewyinat east (location 3) during two summer seasons; 2013 and 2014. Some soil properties of the experimental sites are shown in Table 1.

TABLE 1. Some soil properties of the experimental sites (average the two growing seasons).

\begin{tabular}{|l|c|c|c|}
\hline \multicolumn{1}{|c|}{ Locations } & Shandaweel & Al-Arish & El-Ewyinat east \\
\hline Soil properties & & & 64.70 \\
\hline Sand (\%) & 55.91 & 87.20 & 28.00 \\
\hline Silt (\%) & 11.84 & 7.20 & 7.30 \\
\hline Clay (\%) & 32.25 & 5.60 & Sandy loam \\
\hline Soil texture & Sandy clay & Sandy & 8.27 \\
\hline pH (1:1) & 7.60 & 8.37 & 0.69 \\
\hline EC (ds m-1) & 0.39 & 1.77 & \\
\hline
\end{tabular}

The materials used in this work comprised twelve sunflower genotypes. The origins and some descriptions of these genotypes are given in Table 2. The treatments were distributed in a split plot design with three replications.

Egypt. J. Agron . 37, No.2 (2015) 
TABLE 2. Origins and some descriptions of the used genotypes.

\begin{tabular}{|c|c|c|c|c|c|c|}
\hline \multirow[b]{2}{*}{ No. } & \multirow[b]{2}{*}{ Genotype } & \multirow[b]{2}{*}{ Origin } & \multicolumn{4}{|c|}{ Agronomic characteristics } \\
\hline & & & $\begin{array}{c}\text { Days to } \\
50 \% \\
\text { flowering }\end{array}$ & $\begin{array}{l}\text { Plant height } \\
\text { (cm) }\end{array}$ & $\begin{array}{c}\text { Steam } \\
\text { diameter } \\
(\mathrm{cm})\end{array}$ & $\begin{array}{c}\text { Head } \\
\text { diameter } \\
(\mathrm{cm})\end{array}$ \\
\hline 1 & Line125 & Egypt & 54.00 & 160.67 & 1.80 & 19.17 \\
\hline 2 & Line167 & Egypt & 53.00 & 159.33 & 2.27 & 16.87 \\
\hline 3 & Line235 & Egypt & 52.00 & 162.00 & 1.97 & 20.83 \\
\hline 4 & Line350 & Egypt & 55.00 & 148.33 & 1.97 & 19.33 \\
\hline 5 & Line460 & Egypt & 56.00 & 171.00 & 2.30 & 19.83 \\
\hline 6 & Line 465 & Egypt & 56.33 & 185.67 & 2.40 & 20.93 \\
\hline 7 & Line 120 & Egypt & 55.33 & 185.67 & 2.07 & 18.47 \\
\hline 8 & Line880 & Egypt & 56.00 & 196.00 & 2.40 & 20.40 \\
\hline 9 & Line885 & Egypt & 55.67 & 179.00 & 2.10 & 21.60 \\
\hline 10 & Line990 & Egypt & 58.00 & 132.33 & 1.63 & 19.30 \\
\hline 11 & Sakha 53 & $\begin{array}{l}\text { Local } \\
\text { variety }\end{array}$ & 52.00 & 168.33 & 2.07 & 22.30 \\
\hline 12 & Giza 102 & $\begin{array}{l}\text { Local } \\
\text { variety }\end{array}$ & 44.00 & 133.67 & 1.63 & 21.77 \\
\hline
\end{tabular}

\section{Cultural practices}

Each sub-plot consisted of 4 ridges, $3 \mathrm{~m}$ length and $0.6 \mathrm{~m}$ apart (plot area $=$ $7.2 \mathrm{~m}^{2}$ ). The agricultural practices were maintained as recommended for sunflower in the three locations. Surface irrigation system was applied in Shandaweel while in the others, sprinkler irrigation system was used. Days to $50 \%$ flowering as number of days from sowing to flowering $50 \%$ of plants for each genotype were recorded. At harvest, 10 guarded plants were chosen from the inner two ridges to collect data on the following characters:

1- Plant height in $\mathrm{cm}(\mathrm{PH})$.

2- Head diameter in $\mathrm{cm}$ (HD).

3- Stem diameter in $\mathrm{cm}$ (SD).

4- 100-seed weight in grams (100- SW).

5- Seed yield/plant in grams (SY/P).

6- Seed oil content (oil \%): Oil was extracted by using petroleum ether $\left(60-80^{\circ} \mathrm{C}\right)$ and Soxhelt apparatus according to AOAC (1980).

7- Seed yield (SY) was primarily calculated from plot area and then converted to the unit of $(\mathrm{kg} / \mathrm{fed})$.

8- Oil yield (OY): It was calculated by multiplying seed yield ( $\mathrm{kg} / \mathrm{fed})$ by seed oil percentage $(\%)$. 


\section{Statistical analysis}

Combined analysis of variance over growing seasons and locations was done as outlined by Snedecor \& Cochran (1989). Significant differences among treatment means were detected using least significant difference test (LSD) at $5 \%$ probability level. Assumption of homogeneity of variances was examined before running the combined analysis according to Levene (1960). The interrelationships among oil yield and its related traits were studied at the genotypic and phenotypic levels using the following methodologies:

1- Correlation coefficients between all pairs of studied traits were computed as suggested by Johnson et al. (1955).

2- Path coefficient analysis was subjected as suggested by Wright (1921) and rediscovered by Dewey \& Lu (1959). The method permits to separate the genotypic and phenotypic correlation coefficient between the oil yield (as a resultant variable) and each of related traits (as explanatory variables) into direct effect (path coefficient) and indirect effects (that exerted through the other variables). The genotypic and phenotypic variances ( $\mathrm{Vg}$ and $\mathrm{Vph}$ ), and genotypic and phenotypic coefficient of variation (GCV and PCV), broad sense of heritability were estimated according to Johnson et al. (1955). Genetic advance in terms of percentage of means (with $10 \%$ selection intensity) was estimated as described by Brim et al. (1959).

A BASIC program (Atia, 2007) was used to automate the computations of genotypic and phenotypic correlation coefficients and their corresponding path analyses.

\section{Results and Discussion}

The results of Levene test (1960) proved the homogeneity of variances over growing seasons and locations for all studied characters that permits to apply combined analysis. Accordingly, the mean values of oil yield and its related characters for twelve sunflower genotypes are listed in Table 3.

\section{Mean performance}

It is evident from Table 3 that the differences among studied genotypes were clear and significant for all studied characters indicating wide genetic variation among tested genotypes.

Results displayed that genotype No 10 (Line 990) had the latest in flowering recording (60.5, 48.7 and 54.8 days) over both seasons in the three locations, respectively. On the other hand, the genotype No 12 (Giza 102) was the earliest in flowering recording averages of (46.5, 37.2 and 42.3 days) over both seasons in the three locations, respectively. 
TABLE 3. The mean performance of the studied genotypes obtained from combined analysis over two seasons for some yield traits throw three locations.

\begin{tabular}{|c|c|c|c|c|c|c|c|c|c|c|}
\hline & 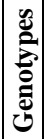 & DF & PH & H D & SD & $\begin{array}{l}\text { 100- } \\
\text { SW }\end{array}$ & SY/P & Oil \% & $\begin{array}{c}\text { SY } \\
(\mathrm{kg} / \mathrm{fed})\end{array}$ & $\begin{array}{c}\text { Oil Y } \\
\text { (kg/fed) }\end{array}$ \\
\hline \multirow{12}{*}{ 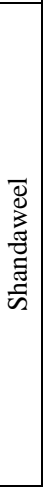 } & 1 & $56.7 \mathrm{~d}$ & $185.7 \mathrm{e}$ & $20.2 \mathrm{e}$ & $2.0 \mathrm{e}$ & $5.7 \mathrm{fg}$ & $62.0 \mathrm{f}$ & $31.8 \mathrm{f}$ & $1176.0 \mathrm{a}$ & $451.5 \mathrm{bcd}$ \\
\hline & 2 & $55.5 \mathrm{e}$ & $184.3 \mathrm{~g}$ & $17.9 \mathrm{~g}$ & $2.5 \mathrm{~b}$ & $7.6 \mathrm{a}$ & $69.3 \mathrm{c}$ & $38.4 \mathrm{c}$ & $1137.7 \mathrm{abc}$ & $448.0 \mathrm{~cd}$ \\
\hline & 3 & $54.5 \mathrm{f}$ & $187.2 \mathrm{c}$ & $21.8 \mathrm{c}$ & $2.2 \mathrm{~d}$ & $5.7 \mathrm{fg}$ & $68.0 \mathrm{~cd}$ & $37.5 \mathrm{c}$ & $1077.7 \mathrm{de}$ & $438.7 \mathrm{~d}$ \\
\hline & 4 & $57.8 \mathrm{c}$ & $173.3 \mathrm{e}$ & $20.3 \mathrm{e}$ & $2.2 \mathrm{p}$ & $5.6 \mathrm{~g}$ & $59.0 \mathrm{~g}$ & $38.1 \mathrm{c}$ & $1112.0 \mathrm{~cd}$ & $449.0 \mathrm{~cd}$ \\
\hline & 5 & $58.5 \mathrm{bc}$ & $195.3 \mathrm{~d}$ & $21.1 \mathrm{~d}$ & $2.5 \mathrm{~b}$ & $7.1 \mathrm{~b}$ & $63.0 \mathrm{f}$ & $31.9 \mathrm{f}$ & $1158.0 \mathrm{ab}$ & $476.2 \mathrm{a}$ \\
\hline & 6 & $58.8 \mathrm{~b}$ & $210.7 \mathrm{c}$ & $21.9 \mathrm{c}$ & $2.6 \mathrm{a}$ & $7.4 \mathrm{ab}$ & $64.0 \mathrm{ef}$ & $32.7 \mathrm{f}$ & $1175.2 \mathrm{a}$ & $466.8 \mathrm{ab}$ \\
\hline & 7 & $57.8 \mathrm{c}$ & $210.0 \mathrm{f}$ & $19.5 \mathrm{f}$ & $2.3 \mathrm{c}$ & $6.4 \mathrm{~d}$ & $66.3 \mathrm{de}$ & $34.0 \mathrm{e}$ & $1179.3 \mathrm{a}$ & $460.6 \mathrm{abc}$ \\
\hline & 8 & $58.5 \mathrm{bc}$ & $221.0 \mathrm{~cd}$ & $21.4 \mathrm{~cd}$ & $2.6 \mathrm{a}$ & $5.9 \mathrm{e}$ & $67.0 \mathrm{~cd}$ & $35.2 \mathrm{~d}$ & $1118.3 \mathrm{bcd}$ & $451.5 \mathrm{bcd}$ \\
\hline & 9 & $58.2 \mathrm{bc}$ & $204.0 \mathrm{~b}$ & $22.6 \mathrm{~b}$ & $2.3 \mathrm{c}$ & $6.0 \mathrm{e}$ & $74.7 \mathrm{~b}$ & $42.5 \mathrm{~b}$ & $1065.0 \mathrm{e}$ & $440.8 \mathrm{~d}$ \\
\hline & 10 & $60.5 \mathrm{a}$ & $157.3 \mathrm{e}$ & $20.3 \mathrm{e}$ & $1.8 \mathrm{f}$ & 5.9 ef & $78.0 \mathrm{a}$ & $46.2 \mathrm{a}$ & $1121.0 \mathrm{bcd}$ & $449.2 \mathrm{~cd}$ \\
\hline & 11 & $54.5 \mathrm{f}$ & $193.3 \mathrm{a}$ & $23.3 \mathrm{a}$ & $2.3 \mathrm{c}$ & $6.7 \mathrm{c}$ & $72.7 \mathrm{~b}$ & $41.8 \mathrm{~b}$ & $1142.7 \mathrm{abc}$ & $415.8 \mathrm{e}$ \\
\hline & 12 & $46.5 \mathrm{~g}$ & $158.7 \mathrm{ab}$ & $22.8 \mathrm{ab}$ & $1.8 \mathrm{f}$ & $7.4 \mathrm{a}$ & $78.67 \mathrm{a}$ & $46.8 \mathrm{a}$ & $987.3 \mathrm{f}$ & $388.7 \mathrm{f}$ \\
\hline \multirow{12}{*}{ 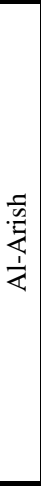 } & 1 & $27.3 \mathrm{bc}$ & $88.3 \mathrm{~g}$ & $11.2 \mathrm{~h}$ & $1.6 \mathrm{e}$ & $4.4 \mathrm{e}$ & $26.4 \mathrm{~d}$ & $34.0 \mathrm{c}$ & $527.7 \mathrm{~b}$ & $213.4 \mathrm{a}$ \\
\hline & 2 & $46.0 \mathrm{~d}$ & $90.0 \mathrm{~g}$ & $12.1 \mathrm{~g}$ & $2.1 \mathrm{~b}$ & $5.4 \mathrm{~b}$ & $25.8 \mathrm{~d}$ & $33.0 \mathrm{e}$ & $534.0 \mathrm{~b}$ & $210.7 \mathrm{a}$ \\
\hline & 3 & $39.8 \mathrm{f}$ & $101.7 \mathrm{e}$ & $9.1 \mathrm{i}$ & $1.8 \mathrm{~d}$ & 4.5 cde & $23.9 \mathrm{e}$ & $30.5 \mathrm{f}$ & $446.3 \mathrm{de}$ & $183.0 \mathrm{e}$ \\
\hline & 4 & $45.8 \mathrm{~d}$ & $96.7 \mathrm{f}$ & $13.8 \mathrm{e}$ & $1.8 \mathrm{~d}$ & $4.4 \mathrm{de}$ & $31.1 \mathrm{c}$ & $37.9 \mathrm{~d}$ & $453.7 \mathrm{~d}$ & $176.8 \mathrm{ef}$ \\
\hline & 5 & $46.8 \mathrm{c}$ & $110.0 \mathrm{~d}$ & $14.7 \mathrm{~cd}$ & $2.1 \mathrm{~b}$ & $5.1 \mathrm{~b}$ & $34.3 \mathrm{~b}$ & $41.2 \mathrm{~b}$ & $524.3 \mathrm{~b}$ & $201.3 \mathrm{bcd}$ \\
\hline & 6 & $48.0 \mathrm{ab}$ & $113.3 \mathrm{~cd}$ & $15.0 \mathrm{bc}$ & $2.2 \mathrm{a}$ & $6.3 \mathrm{a}$ & $34.0 \mathrm{~b}$ & $41.2 \mathrm{~b}$ & $531.0 \mathrm{~b}$ & $193.8 \mathrm{~d}$ \\
\hline & 7 & $47.0 \mathrm{c}$ & $116.7 \mathrm{bc}$ & $15.7 \mathrm{a}$ & $1.9 \mathrm{c}$ & $5.4 \mathrm{~b}$ & $31.7 \mathrm{c}$ & $39.2 \mathrm{c}$ & $555.0 \mathrm{a}$ & $205.5 \mathrm{abc}$ \\
\hline & \begin{tabular}{|l|}
8 \\
\end{tabular} & $45.3 \mathrm{~d}$ & $118.3 \mathrm{~b}$ & $14.6 \mathrm{~d}$ & $2.2 \mathrm{a}$ & $4.8 \mathrm{c}$ & $31.0 \mathrm{c}$ & $37.8 \mathrm{~d}$ & $520.2 \mathrm{~b}$ & $198.3 \mathrm{~cd}$ \\
\hline & \begin{tabular}{|l|}
9 \\
\end{tabular} & $47.3 \mathrm{bc}$ & $125.0 \mathrm{a}$ & $14.8 \mathrm{bcd}$ & $1.9 \mathrm{c}$ & $4.7 \mathrm{~cd}$ & $35.2 \mathrm{~b}$ & $41.7 \mathrm{~b}$ & $430.7 \mathrm{e}$ & $161.5 \mathrm{~g}$ \\
\hline & 10 & $48.7 \mathrm{a}$ & $110.0 \mathrm{~d}$ & $15.1 \mathrm{~b}$ & $1.4 \mathrm{f}$ & $4.0 \mathrm{f}$ & $31.2 \mathrm{c}$ & $38.3 \mathrm{~cd}$ & $457.3 \mathrm{~d}$ & $173.3 \mathrm{f}$ \\
\hline & 11 & $43.3 \mathrm{e}$ & $90.0 \mathrm{~g}$ & $10.9 \mathrm{~h}$ & $1.9 \mathrm{c}$ & $4.5 \mathrm{cde}$ & $34.7 \mathrm{~b}$ & $41.5 \mathrm{~b}$ & $500.7 \mathrm{c}$ & $182.5 \mathrm{e}$ \\
\hline & 12 & $37.2 \mathrm{~g}$ & $101.7 \mathrm{e}$ & $12.8 \mathrm{f}$ & $1.4 \mathrm{f}$ & $6.2 \mathrm{a}$ & $37.0 \mathrm{a}$ & $43.8 \mathrm{a}$ & $554.0 \mathrm{a}$ & $208.4 \mathrm{ab}$ \\
\hline \multirow{12}{*}{ 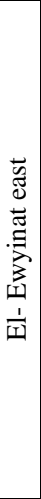 } & \begin{tabular}{|l|}
1 \\
\end{tabular} & $53.0 \mathrm{~cd}$ & $155.0 \mathrm{f}$ & $14.0 \mathrm{f}$ & $2.1 \mathrm{e}$ & $5.4 \mathrm{e}$ & $29.0 \mathrm{f}$ & $39.7 \mathrm{~cd}$ & $434.2 \mathrm{bc}$ & $303.1 \mathrm{e}$ \\
\hline & \begin{tabular}{|l|}
2 \\
\end{tabular} & $52.0 \mathrm{f}$ & $156.7 \mathrm{f}$ & $20.3 \mathrm{e}$ & $2.6 \mathrm{~b}$ & $6.3 \mathrm{bc}$ & 50.0 ef & $35.2 \mathrm{e}$ & $839.5 \mathrm{~b}$ & $306.4 \mathrm{de}$ \\
\hline & 3 & $46.0 \mathrm{~h}$ & $168.3 \mathrm{~d}$ & $17.5 \mathrm{~g}$ & $2.3 \mathrm{~d}$ & $5.7 \mathrm{~d}$ & $47.0 \mathrm{~g}$ & $41.7 \mathrm{~b}$ & $765.5 \mathrm{f}$ & $308.8 \mathrm{~d}$ \\
\hline & \begin{tabular}{|l|}
4 \\
\end{tabular} & $52.5 \mathrm{e}$ & $165.0 \mathrm{e}$ & $21.3 \mathrm{~d}$ & $2.3 \mathrm{~d}$ & $5.7 \mathrm{~d}$ & $53.4 \mathrm{~d}$ & $38.8 \mathrm{~d}$ & $742.7 \mathrm{~g}$ & $280.9 \mathrm{~h}$ \\
\hline & 5 & $53.2 \mathrm{c}$ & $175.0 \mathrm{c}$ & $22.2 \mathrm{c}$ & $2.6 \mathrm{ab}$ & $6.4 \mathrm{bc}$ & $59.5 \mathrm{a}$ & $40.8 \mathrm{~b}$ & $820.5 \mathrm{~d}$ & $311.9 \mathrm{~cd}$ \\
\hline & 6 & $53.8 \mathrm{~b}$ & $172.5 \mathrm{c}$ & $22.5 b c$ & $2.7 \mathrm{a}$ & $7.1 \mathrm{a}$ & $56.7 \mathrm{~b}$ & $43.3 \mathrm{a}$ & $825.2 \mathrm{~cd}$ & $314.9 \mathrm{c}$ \\
\hline & 7 & $52.7 \mathrm{de}$ & $174.2 \mathrm{c}$ & $23.4 \mathrm{a}$ & $2.4 \mathrm{c}$ & $6.5 \mathrm{~b}$ & $56.0 \mathrm{bc}$ & $35.7 \mathrm{e}$ & $862.5 \mathrm{a}$ & $337.9 \mathrm{a}$ \\
\hline & 8 & $52.3 \mathrm{ef}$ & $180.0 \mathrm{~b}$ & $22.7 \mathrm{bc}$ & $2.7 \mathrm{a}$ & $6.2 \mathrm{c}$ & $50.7 \mathrm{e}$ & $36.2 \mathrm{~d}$ & $833.2 \mathrm{bc}$ & $331.9 \mathrm{~b}$ \\
\hline & 9 & $53.8 \mathrm{~b}$ & $192.5 \mathrm{a}$ & $23.0 \mathrm{ab}$ & $2.4 \mathrm{c}$ & $5.8 \mathrm{~d}$ & $58.8 \mathrm{a}$ & $33.3 \mathrm{f}$ & $720.5 \mathrm{~h}$ & $262.9 \mathrm{I}$ \\
\hline & 10 & $54.8 \mathrm{a}$ & $179.2 \mathrm{~b}$ & $22.9 \mathrm{ab}$ & $1.9 \mathrm{f}$ & $5.4 \mathrm{e}$ & $54.7 \mathrm{~cd}$ & $38.8 \mathrm{~d}$ & $750.3 \mathrm{~g}$ & $291.4 \mathrm{f}$ \\
\hline & 11 & $49.5 \mathrm{~g}$ & $157.5 \mathrm{f}$ & $18.9 \mathrm{f}$ & $2.4 \mathrm{c}$ & $5.9 \mathrm{~d}$ & $56.9 \mathrm{~b}$ & $43.2 \mathrm{a}$ & $791.2 \mathrm{e}$ & $286.1 \mathrm{~g}$ \\
\hline & 12 & $42.3 \mathrm{i}$ & $167.5 \mathrm{de}$ & $21.0 \mathrm{~d}$ & $1.9 \mathrm{f}$ & $7.2 \mathrm{a}$ & $60.2 \mathrm{a}$ & $40.7 \mathrm{bc}$ & $843.8 \mathrm{~b}$ & $310.7 \mathrm{~cd}$ \\
\hline
\end{tabular}

Means followed by the same letters within each column do not differ significantly according to Duncan's Multiple Range test at the 5\% level. 
Genotype No 11 check cultivar (Sakha 53) had the tallest plants recording $(193.3 \mathrm{~cm})$ at the first location, while Genotype No 9 (Line 885) had the highest values $(125.0$ and $192.5 \mathrm{~cm}$ ) in the second and third location, respectively. Considering head diameter, check cultivar genotype Sakha 53 gave the highest values at the first location $(23.3 \mathrm{~cm})$ and genotype Line 120 had the best value at the second and third locations with value being $(15.7$ and $23.4 \mathrm{~cm})$, respectively, without significant differences between them.

The elite genotypes Line 465 and Line 880 surpassed the two check cultivars (Sakha 53 and Giza 102) recording the maximum values of stem diameter (2.6, 2.2 and $2.7 \mathrm{~cm})$. For100-seed weight, genotype no. 12 recorded the highest values $(7.4$ and $7.4 \mathrm{~g})$ in the first and third locations, while in the second location genotype no. 6 came in the first $(6.3 \mathrm{~g})$.With respect to seed yield/plant, the best values reached to 78.0 and $78.67 \mathrm{~g}$ by the genotypes Line 990 and Giza 102 in the first location, $37.0 \mathrm{~g}$ by Giza 102 in the second location and 59.5, 58.8 and $60.2 \mathrm{~g}$ by Line 460, Line 885 and Giza 102 in the third location.

Regarding seed oil content percentage, the best genotypes were; Line 999 and Giza 102 (46.5 and 46.8\%), Giza 102 (43.8\%) and Line 465 and Sakha 53 (43.3 and $43.2 \%)$ at three locations, respectively.

Concerning Seed yield/fed., it is obvious that genotypes no.1, 6 and 7, no.7 and 12 and no. 7 had the maximum values (1176.0, 1175.2 and $1179.3 \mathrm{~kg} / \mathrm{fed}$ ), (555.0 and $554.0 \mathrm{~kg} / \mathrm{fed})$ and $(862.5 \mathrm{~kg} / \mathrm{fed})$, respectively. With regard to oil yield, data in Table 3 indicated that genotypes no. 5, 1 and 2 and no. 7 surpassed the other genotypes, where it gave the highest estimates by $476.2 \mathrm{~kg} / \mathrm{fed}, 213.4$ and $210.7 \mathrm{~kg} / \mathrm{fed}$ and $337.9 \mathrm{~kg} / \mathrm{fed}$ at the three locations, respectively. Similar results have been concluded by Sharief (1998), Vega et al. (2002), Allam et al. (2003) and Abdou et al. (2011) who found significant differences among studied genotypes of sunflower for seed and oil yields and most studied characters.

\section{Genetic parameters}

Such considerable range of variation provided a good opportunity for yield improvement. Genotypic and phenotypic coefficients of variation (GCV and PCV), broad sense heritability $\left(\mathrm{h}^{2}\right)$, and genetic advance expressed as percent of mean for the six characteristics are shown in Table 4. The phenotypic coefficient of variation (PCV) was generally higher than the genotypic coefficient of variation $(\mathrm{GCV})$ for the studied characters, but in many cases, the two values differed only slightly which reflect some what the effect of environment on the expression of traits. According, the selection would be effective to improve these traits among the studied genotypes. Similar results were reported by Humera et al. (2014). High values of genotypic and phenotypic coefficients of variation were shown for head diameter $(7.15,15.88$ and 8.61) and $(7.69,19.08$ and 9.56), seed yield/plant $(9.49,14.79$ and 7.71) and (10.14, 20.92 and 8.55), 100-seed weight (11.06, 14.18 and 8.94) and (11.94, 15.3 and 10.79), stem diameter Egypt. J. Agron. 37, No.2 (2015) 
$(11.89,14.05$ and 11.05$)$ and $(12.07,14.00$ and 11.63), plant height $(10.59,12.33$ and 5.98) and (12.25,16.63 and 7.04), oil yield (5.12, 9.46 and 6.49) and (6.17, 15.23 and 7.55) and seed yield/fed (5.46, 8.87 and 5.71) and (6.17, 15.23 and $7.55)$ in the three locations, respectively.

While low estimates were observed with the seed oil content percentage $(2.53,3.50$ and 3.34$)$ and $(5.00,4.65$ and 4.43$)$ and days to $50 \%$ flowering $(6.45$, 7.60 and 7.01$)$ and $(6.58,7.76$ and 7.12$)$ in the three locations, respectively.

With regard to the broad sense heritabilities, the data also revealed that estimates ranged from moderately to high for all studied traits at the three locations, except for seed oil content $\%$ and seed yield ( $\mathrm{kg} / \mathrm{fed}$.) in the first and second locations, respectively which had low values. .In order to predicting the selection effect, heritability accompanied with genetic advance is rather used than heritability alone.

In the same frame, it has been emphasized that without considering genetic advance, the heritability values $\left(\mathrm{h}^{2}\right)$ would not be practically important in selection based on phenotypic appearance (Johnson et al., 1955).

The data in the Table 4 present that, high values of heritability accompanied with high values of genetic advance (as \% of mean) were obtained with stem diameter and weight of 100 seeds in three locations, indicating the importance of the additive gene effects. High heritability in the third location for stem diameter $(90 \%)$ and head diameter $(81 \%)$ coupled with high genetic advance $(18.48 \%)$ and $(13.64 \%)$, respectively. High heritability estimates accompanied with high genetic advance is rather useful than high heritability alone for predicting the selection effect (Farhatullah et al., 2006 and Humera et al., 2014) .

As shown in Table 4, high estimates of heritability accompanied with moderate genetic advance were observed with seed yield/plant in the first location, with days to $50 \%$ flowering in the second location, also in the third location, seed yield/plant had high estimates of heritability coupled with moderate genetic advance. These results indicate that additive gene effects are more important and the improvement can be applied through selection for this trait (Labana et al., 1980). On the other hand, low values of heritability accompanied with low genetic advance in the three locations were obtained with seed oil percentage indicative of non-additive gene effects. Therefore, a limited scope for improvement of this trait is expected under the studied genotypes. The current conclusions are supported by Johnson et al. (1955) who emphasized that selection can be making safely with high values of heritability and genetic advance. 
TABLE 4. Estimates of genetic parameters for some yield traits in sunflower genotypes throw three locations over two seasons.

\begin{tabular}{|l|c|c|c|c|c|c|}
\hline \multirow{3}{*}{ Traits } & Locations & \multicolumn{5}{|c|}{ Genetic parameters } \\
\cline { 3 - 7 } & & Mean & GCV & PCV & $\mathbf{h}^{\mathbf{2}}$ & $\begin{array}{c}\text { GA } \\
\text { (\% mean) }\end{array}$ \\
\hline \multirow{4}{*}{ DF } & Shandaweel & 56.49 & 6.45 & 6.58 & 0.96 & 11.14 \\
& El-arash & 45.22 & 7.60 & 7.76 & $\mathbf{0 . 9 6}$ & $\mathbf{1 3 . 1 1}$ \\
& El- Ewyinat east & 51.33 & 7.01 & 7.12 & 0.97 & 12.14 \\
\hline \multirow{4}{*}{ PH } & Shandaweel & 190.07 & 10.59 & 12.25 & 0.75 & 16.10 \\
& El-arash & 105.14 & 12.33 & 16.63 & 0.55 & 16.09 \\
& El- Ewyinat east & 170.28 & 5.98 & 7.04 & 0.72 & 8.93 \\
\hline \multirow{4}{*}{ H D } & Shandaweel & 21.09 & 7.15 & 7.69 & 0.86 & 11.69 \\
& El-arash & 13.31 & 15.88 & 19.08 & 0.69 & 23.25 \\
& El- Ewyinat east & 21.23 & 8.61 & 9.56 & 0.81 & 13.64 \\
\hline \multirow{3}{*}{ S D } & Shandaweel & 2.25 & 11.89 & 12.07 & 0.97 & 20.60 \\
& El-arash & 1.85 & 14.05 & 14.00 & 0.91 & 23.53 \\
& El- Ewyinat east & 2.35 & 11.05 & 11.63 & $\mathbf{0 . 9 0}$ & $\mathbf{1 8 . 4 8}$ \\
\hline \multirow{3}{*}{ 100-SW } & Shandaweel & 6.46 & 11.06 & 11.49 & 0.93 & 18.73 \\
& El-arash & 4.96 & 14.18 & 15.03 & 0.89 & 23.55 \\
& El- Ewyinat east & 6.12 & 8.94 & 10.79 & 0.69 & 13.04 \\
\hline \multirow{3}{*}{ SY/P } & Shandaweel & 68.56 & 9.47 & 10.14 & $\mathbf{0 . 8 7}$ & $\mathbf{1 5 . 5 8}$ \\
& El-arash & 31.37 & 14.79 & 20.92 & 0.50 & 18.40 \\
& El- Ewyinat east & 54.40 & 7.71 & 8.55 & $\mathbf{0 . 8 1}$ & $\mathbf{1 2 . 2 4}$ \\
\hline \multirow{3}{*}{ Oil \% } & Shandaweel & 39.81 & 2.53 & 5.00 & $\mathbf{0 . 2 6}$ & $\mathbf{2 . 2 5}$ \\
& El-arash & 38.36 & 3.50 & 4.65 & $\mathbf{0 . 5 7}$ & $\mathbf{4 . 6 5}$ \\
& El- Ewyinat east & 37.88 & 3.34 & 4.43 & $\mathbf{0 . 5 7}$ & $\mathbf{4 . 4 2}$ \\
\hline \multirow{2}{*}{ fed) } & Shandaweel & 1120.8 & 5.46 & 6.47 & 0.71 & 8.11 \\
& El-arash & 502.90 & 8.87 & 16.35 & 0.29 & 8.46 \\
& El- Ewyinat east & 802.42 & 5.71 & 6.05 & 0.89 & 9.50 \\
\hline & Shandaweel & 444.73 & 5.12 & 6.17 & 0.69 & 7.49 \\
& El-arash & 192.37 & 9.46 & 15.23 & 0.39 & 10.35 \\
& El- Ewyinat east & 303.91 & 6.49 & 7.55 & 0.74 & 9.82 \\
\hline & & & & & &
\end{tabular}

\section{Correlation matrix}

Genotypic (above diagonal) and phenotypic (below diagonal) correlation coefficients among oil yield and its related characters, estimated in location 1, location 2 and location 3 are given in Table 5. Generally, there was clear convergence between most genotypic and phenotypic correlation coefficients considering the value or sign in three locations indicating that the observed associations among most studied characters may be mostly attributed to genetic effects. Results showed that the most effective relationships to sunflower breeder, in location1, were those between oil yield and each of $50 \%$ flowering $\left(0.91^{* *}\right.$ and $\left.0.76^{* *}\right)$, plant height $\left(0.689^{* *}\right.$ and $\left.0.324 * *\right)$, stem diameter $(0.609 * *$ and $0.527 * *)$, head diameter $\left(-0.498^{* *}\right.$ and $\left.-0.29 *\right)$ and seed yield/ plant $\left(-0.473 * *\right.$ and $\left.-0.443^{* *}\right)$ at Egypt. J. Agron . 37, No.2 (2015) 
the genotypic and phenotypic levels, respectively. The high positive genotypic correlation between each of the aforementioned characters and oil yield reflected the inherent associations; therefore, the breeder can obtain high yielding genotypes through selection for one or more of these characters, especially if they proved to be more contributors to yield variation as lately shown.

On the other side, the yield contributors exhibited various trends of correlations among themselves. There was negative and highly significant genotypic or phenotypic association between $50 \%$ flowering and each of head diameter $(-0.3 * *$ and $\left.-0.26^{*}\right), 100$-seed weight $\left(-0.34^{* *}\right.$ and $\left.-0.33^{* *}\right)$ and seed weight /plant $\left(-0.28^{*}\right.$ and $\left.-0.27^{*}\right)$ and plant height with seed weight/ plant $\left(-0.27^{*}\right.$ and $\left.-0.27^{*}\right)$ while on the reverse, $50 \%$ flowering had positive and highly significant genotypic and phenotypic associations with each of plant height $(0.50 * *$ and $0.42 * *)$ and stem diameter $\left(0.45^{* *}\right.$ and $\left.0.44^{* *}\right)$. However, plant height was found to be highly significant and positively correlated with stem diameter $\left(0.90^{* *}\right.$ and $\left.0.74 * *\right)$ and the same results showed with stem diameter with 100 -seed weight $\left(0.33^{* *}\right.$ and $\left.0.31 * *\right)$ at the genotypic and phenotypic, respectively.

TABLE 5. Genotypic (above diagonal) and phenotypic (below diagonal) correlation coefficients among oil yield (kg/fed) and its related characters evaluated individually under three locations over the two seasons.

\begin{tabular}{|c|c|c|c|c|c|c|c|c|}
\hline Locations & Traits & DF & PH & H D & S D & 100-SW & SY/P & Oil Y \\
\hline \multirow{7}{*}{ Shandaweel } & $\mathrm{DF}$ & 1 & $0.50 * *$ & $-0.3^{* * *}$ & $0.45 * *$ & $-0.34 * *$ & $-0.28 *$ & $0.91 * *$ \\
\hline & $\mathrm{PH}$ & $0.42 * *$ & 1 & 0.19 & $0.90 * *$ & 0.04 & $-0.27 *$ & $0.69 * *$ \\
\hline & H D & $-0.26^{*}$ & 0.05 & 1 & -0.04 & 0.01 & $-0.34 * *$ & $-0.498 * *$ \\
\hline & S D & $0.44 * *$ & $0.74 * *$ & -0.03 & 1 & $\mathbf{0 . 3 3} * *$ & $0.25^{*}$ & $0.609 * *$ \\
\hline & $100-\mathrm{SW}$ & $-0.33 * *$ & 0.06 & -0.01 & $0.31 * *$ & 1 & $0.25^{*}$ & -0.069 \\
\hline & $\mathrm{SY} / \mathrm{P}$ & $-0.27 *$ & -0.10 & $0.32 * *$ & $-0.33 * *$ & 0.21 & 1 & $-0.473 * *$ \\
\hline & Oil Y & $0.76 * *$ & $0.324 * *$ & $-0.29 *$ & $0.527 * *$ & -0.112 & $-0.443 * *$ & \\
\hline \multirow{7}{*}{ Al-Araish } & DF & 1 & $\mathbf{0 . 3 7 * *}$ & $0.64 * *$ & $0.37 * *$ & -0.22 & 0.09 & -0.002 \\
\hline & PH & $0.29 *$ & 1 & 0.78** & $0.46^{* * *}$ & 0.22 & $0.55 * *$ & -0.098 \\
\hline & H D & $0.54 * *$ & $0.83 * *$ & 1 & $0.36 * *$ & $0.29 * *$ & $0.62 * *$ & 0.032 \\
\hline & S D & $0.34 * *$ & 0.18 & 0.18 & 1 & $0.34 * *$ & 0.21 & $0.326 * *$ \\
\hline & $100-\mathrm{SW}$ & 0.22 & $0.25^{*}$ & $0.29 * *$ & $0.27 *$ & 1 & $0.42 * *$ & $0.519 * *$ \\
\hline & $\mathrm{SY} / \mathrm{P}$ & $0.86 * *$ & $0.74 * *$ & $0.73 * *$ & -0.01 & $0.37 * *$ & 1 & 0.085 \\
\hline & Oil Y & 0.022 & 0.438 ** & $0.426 * *$ & 0.038 & 0.413 ** & $0.561^{* *}$ & \\
\hline \multirow{7}{*}{$\begin{array}{l}\text { El-ewynat } \\
\text { east }\end{array}$} & $\mathrm{DF}$ & 1 & 0.31* & $0.56 * *$ & $0.40 * *$ & $-0.37 * *$ & -0.01 & -0.129 \\
\hline & $\mathrm{PH}$ & $0.28 *$ & 1 & $0.74 * *$ & 0.16 & -0.04 & $0.41 * *$ & -0.166 \\
\hline & H D & $0.49 * *$ & 0.70** & 1 & $\mathbf{0 . 2 3}^{*}$ & $0.28^{*}$ & 0.58** & 0.082 \\
\hline & S D & $0.37 * *$ & 0.19 & $0.27 *$ & 1 & $\mathbf{0 . 3 4} * *$ & -0.01 & $0.301 * *$ \\
\hline & $100-\mathrm{SW}$ & $-0.26 *$ & 0.14 & $0.35 * *$ & $0.35 * *$ & 1 & $0.53 * *$ & $0.493 * *$ \\
\hline & $\mathrm{SY} / \mathrm{P}$ & -0.02 & $0.37 * *$ & $0.50 * *$ & 0.01 & $0.42 * *$ & 1 & -0.198 \\
\hline & Oil Y & -0.108 & -0.001 & 0.223 & $0.310 * *$ & $0.51 * *$ & -0.122 & \\
\hline
\end{tabular}

$*$ and **: Significant and highly significant at 0.05 and 0.01 probability levels, respectively. 
Results also cleared that the most effective relationships in location 2, were those observed between oil yield and each of 100 -seed weight $(0.519 * *$ and $\left.0.413^{* *}\right)$ at the genotypic and phenotypic levels, respectively. Furthermore, high positive and highly significant genotypic correlation were obtained between oil yield and each of stem diameter $\left(0.326^{* *}\right)$ and 100 -seed weight $(0.519 * *)$. Also, high positive and highly significant phenotypic correlation between oil yield and each of plant height $\left(0.438^{* *}\right)$, head diameter $\left(0.426^{* *}\right)$, 100-seed weight $\left(0.413^{* *}\right)$ and seed yield/plant $\left(0.561^{* *}\right)$.

The yield contributors exhibited various trends of correlations among themselves. There was positive and highly significant genotypic or phenotypic association between days to $50 \%$ flowering had positive and highly significant genotypic and phenotypic associations with each of plant height $\left(0.37^{* *}\right.$ and $0.29 *)$, head diameter $(0.64 * *, 0.54 * *)$ and stem diameter $(0.37 * *$ and $0.34 * *)$. However, plant height was found to be highly significant and positively correlated with head diameter $\left(0.78^{* *}\right.$ and $\left.0.83^{* *}\right)$ and seed weight /plant $(0.55 * *$ and $0.74 * *)$. Head diameter was found to be highly significant and positively correlated with 100 -seed weight $(0.29 * *$ and $0.29 * *)$ and seed yield/plant $(0.62 * *$ and $0.73 * *)$. Also highly significant positive correlation were found between stem diameter and 100-seed weight $\left(0.34^{* *}\right.$ and $\left.0.27^{* *}\right)$ and between 100 -seed weight and seed weight /plant $(0.42 * *$ and $0.37 * *)$ at the genotypic and phenotypic levels, respectively.

The results in Table 5 also proved that the relationships in location 3. Highly significant positive associations were obtained between oil yield and each of stem diameter $\left(0.301^{* *}\right.$ and $\left.0.310^{* *}\right)$ and 100 -seed weight $\left(0.493^{* *}\right.$ and $\left.0.510^{* *}\right)$ at the genotypic and phenotypic levels, respectively. The high positive genotypic correlation between each of the aforementioned characters and oil yield reflected the inherent associations; therefore, the breeder can obtain high yielding genotypes through selection for one or more of these characters, especially if they proved to be more contributors to yield variation as lately shown.

On the other side, the yield attributers exhibited various trends of correlations among themselves. The remainder correlation coefficients among studied characters were mostly negligible and insignificant. Days to $50 \%$ flowering had positive and highly significant genotypic and phenotypic associations with each of head diameter $\left(0.56^{* *}\right.$ and $\left.0.49 * *\right)$ and stem diameter $\left(0.40^{* *}\right.$ and $\left.0.37 * *\right)$. Also, plant height was found to be highly significant and positively correlated with stem diameter $(0.74 * *$ and $0.70 * *)$ and seed weight /plant $(0.41 * *$ and $0.37 * *)$ at the genotypic and phenotypic levels, respectively. Highly significant positive correlations were also found between head diameter and each of with stem diameter $\left(0.23^{*}\right.$ and $\left.0.27 *\right), 100$-seed weight $\left(0.28^{*}\right.$ and $\left.0.35^{* *}\right)$ and seed yield/plant $\left(0.58^{* *}\right.$ and $\left.0.50 * *\right)$ at the genotypic and phenotypic levels, respectively. The same trend were obtained between stem diameter and 100-seed weight $\left(0.34^{* *}\right.$ and $\left.0.35^{* *}\right)$, and between 100 -seed weight and seed weight / plant $(0.53 * *$ and $0.42 * *)$ at the genotypic and phenotypic, respectively.

Egypt. J. Agron . 37, No.2 (2015) 
Generally, the highly significant positive genotypic relationship between any characters indicates that the improvement predicted under selection for one of them, would automatically extended to the other. These findings are in conflict with those obtained by Hladni et al. (2010) who found highly significant and negatively associations between stem diameter, total leaf area, head diameter and 100 seed weight on one side and seed oil content on the other. This discrepancy in results may be attributed to the used breeding materials and the environmental conditions. In fact, decisions of selection depending only on correlation coefficients may not always be effective because it measures the mutual association between a pair of traits neglecting the complicated interrelationships among all traits (Kang, 1994). Therefore, the correlation procedure may not provide a deep imagine about the importance of each component in the structure of oil yield. The path analysis can efficiently play this vital role.

\section{Path analysis}

Information that has been obtained from the correlations can be augmented by dividing correlations into direct and indirect influences of a particular set of causal interrelationships.

In such cases, the correlation coefficients may be confounded with indirect effects due to common association inherent in trait interrelationships. So, path coefficient analysis has proven useful in giving more information that describes the casual relationships such as yield and its attributers. In the present study, the resultant variable was oil yield while the remaining characters represented the casual variables. The matrix of direct and joint effects six predictor characters on oil yield is shown in Table 6 .

Positive direct effects were recorded for all oil yield attributes except head diameter and seed yield/plant (-0.37 and-0.15) in genotypic level, plant height, head diameter and seed weight /plant $(-0.18,-0.02$ and-0.20) in phenotypic path coefficients at location 1 . Results in Table 6 showed that positive direct effects for all oil yield attributes except plant height, head diameter $(-0.31$ and -0.20$)$ in genotypic level and head diameter and stem diameter (-0.019 and-0.09) in phenotypic path coefficients at location 2 .

On the other hand, data of location 3 cleared that positive direct effects were obtained for all oil yield attributes except days to $50 \%$ flowering , plant height and seed yield/plant (-0.10, -0.14 and-0.71) and $(-0.31,-0.24$ and -0.51$)$ in genotypic and phenotypic levels, respectively.

The maximum direct effects were observed with days to $50 \%$ flowering $(0.65$ and 0.70) at location 1 and with 100-seed weight at location 2 and 3 (0.62 and $0.32)$ and $(0.69$ and 0.40$)$ considering the genotypic and phenotypic levels. 
It is noticed that, the path analysis gave different picture from what the correlation coefficient did. For example, the simple correlation coefficients (at genotypic and phenotypic levels) between oil yield and each of plant height and stem diameter which were positive and highly significant at location 1 , also between oil yield and 100-seed weight at location 2 and also between oil yield and each of stem diameter and 100-seed weight at location 3 (Table 5). However, separation of the indirect effects from correlation coefficients through the path analysis gave different picture, where these traits had trivial effect on oil yield (Table 6).

TABLE 6. The direct and indirect effects of six predictor characters on oil yield $(\mathrm{kg} / \mathrm{fed})$ at genotypic and phenotypic levels evaluated individually under three locations over the two seasons.

\begin{tabular}{|c|c|c|c|c|c|c|c|c|}
\hline Location & Level & Traits & DF & PH & H D & S D & 100-SW & SY/P \\
\hline \multirow{12}{*}{ 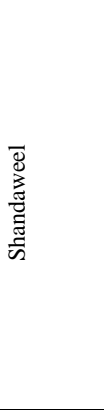 } & \multirow{6}{*}{ Genotypic } & DF & 0.65 & 0.16 & 0.08 & 0.02 & -0.02 & 0.03 \\
\hline & & PH & 0.33 & $\underline{0.44}$ & -0.05 & 0.01 & 0.01 & 0.06 \\
\hline & & H D & -0.19 & 0.08 & $\underline{-0.37}$ & -0.01 & 0.01 & -0.04 \\
\hline & & S D & 0.29 & 0.40 & 0.02 & $\underline{0.05}$ & 0.02 & 0.04 \\
\hline & & 100-SW & -0.22 & 0.02 & -0.01 & 0.02 & $\underline{0.09}$ & -0.03 \\
\hline & & SY/P & -0.18 & -0.12 & -0.15 & -0.02 & 0.02 & $\underline{-0.15}$ \\
\hline & \multirow{6}{*}{ Phenotypic } & DF & 0.70 & -0.08 & 0.01 & 0.11 & -0.30 & 0.05 \\
\hline & & PH & 0.29 & $\underline{-0.18}$ & -0.01 & 0.19 & 0.01 & $\underline{0.02}$ \\
\hline & & H D & -0.18 & -.01 & $\underline{-0.02}$ & 0.01 & 0.01 & -0.07 \\
\hline & & S D & 0.31 & -0.13 & 0.01 & $\underline{0.26}$ & 0.23 & 0.07 \\
\hline & & 100-SW & -0.23 & -0.01 & 0.01 & $\overline{0.08}$ & 0.09 & -0.04 \\
\hline & & SY/P & -0.19 & 0.02 & -0.08 & -0.08 & 0.12 & -0.20 \\
\hline \multirow{12}{*}{ 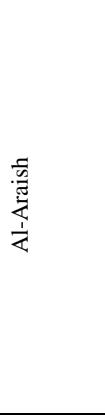 } & \multirow{6}{*}{ Genotypic } & DF & $\underline{0.30}$ & -0.12 & -0.12 & 0.08 & -0.14 & 0.01 \\
\hline & & PH & 0.11 & $\underline{-0.31}$ & -0.15 & 0.10 & 0.13 & 0.02 \\
\hline & & H D & 0.19 & -0.24 & $\underline{-0.20}$ & 0.08 & 0.18 & 0.03 \\
\hline & & S D & 0.11 & -0.14 & -0.07 & 0.21 & 0.21 & 0.01 \\
\hline & & 100-SW & -0.07 & -0.07 & -0.06 & 0.07 & $\underline{0.62}$ & 0.02 \\
\hline & & SY/P & 0.03 & -0.17 & -0.12 & 0.05 & 0.26 & 0.04 \\
\hline & \multirow{6}{*}{ Phenotypic } & DF & $\underline{0.14}$ & 0.04 & -0.10 & -0.23 & -0.07 & 0.04 \\
\hline & & PH & 0.04 & $\underline{0.15}$ & -0.16 & -.02 & 0.08 & 0.34 \\
\hline & & H D & 0.08 & 0.12 & $\underline{-.019}$ & -.02 & 0.10 & 0.34 \\
\hline & & S D & 0.05 & 0.03 & -0.03 & $\underline{-0.09}$ & 0.09 & -0.01 \\
\hline & & 100-SW & -0.03 & 0.04 & -0.06 & -0.02 & $\underline{0.32}$ & 0.17 \\
\hline & & SY/P & 0.01 & 0.11 & -0.14 & .01 & 0.12 & 0.46 \\
\hline \multirow{12}{*}{ 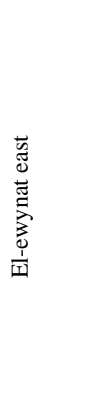 } & \multirow{6}{*}{ Genotypic } & DF & $\underline{-0.10}$ & -0.04 & 0.22 & 0.01 & -0.23 & 0.01 \\
\hline & & PH & -0.03 & $\underline{-0.14}$ & 0.29 & 0.01 & -0.02 & -0.27 \\
\hline & & H D & -0.05 & -0.10 & $\underline{0.43}$ & 0.01 & 0.18 & -0.39 \\
\hline & & S D & -0.04 & -0.02 & $\overline{0.10}$ & $\underline{0.04}$ & 0.22 & 0.01 \\
\hline & & 100-SW & 0.04 & 0.01 & 0.12 & 0.01 & $\underline{0.69}$ & -0.35 \\
\hline & & SY/P & 0.01 & -0.06 & 0.25 & 0.01 & 0.37 & -0.71 \\
\hline & \multirow{6}{*}{ Phenotypic } & DF & $\underline{-0.31}$ & -0.07 & 0.30 & 0.07 & -0.11 & 0.01 \\
\hline & & PH & -0.09 & $\underline{-0.24}$ & -0.42 & 0.03 & 0.06 & -0.17 \\
\hline & & H D & -0.13 & -0.17 & $\underline{0.60}$ & 0.05 & 0.14 & -0.25 \\
\hline & & S D & -0.12 & -0.04 & 0.16 & $\underline{0.18}$ & 0.14 & -0.01 \\
\hline & & 100-SW & 0.08 & -0.03 & 0.21 & 0.06 & $\underline{0.40}$ & -0.21 \\
\hline & & SY/P & 0.01 & -0.09 & 0.29 & 0.01 & 0.17 & -0.51 \\
\hline
\end{tabular}

Shadwy and bold cell indicate to the direct effects.

Egypt. J. Agron . 37, No.2 (2015) 
Concerning the indirect effects in location 1 , it is noted that the highest positive effect on oil yield were recorded from steam diameter through each of plant height and days to $50 \%$ flowering ( 0.40 and 0.29 ) at genotypic level, while via each of days to $50 \%$ flowering and 100 -seed weight $(0.31$ and 0.23$)$ at genotypic and phenotypic levels, respectively. Furthermore, high values of genotypic and phenotypic positive indirect effects were noticed with days to $50 \%$ flowering via plant height and plant height via steam diameter. However, 100 -seed weight had maximum negative indirect effects on oil yield via days to $50 \%$ flowering $(-0.22$ and -0.23$)$ at genotypic and phenotypic levels, respectively. In location 2 , the results revealed that, steam diameter via 100 seed weight had the highest genotypic positive indirect effect on oil yield (0.21). On the other hand, the highest phenotypic indirect effects wee recorded from each of plant height and head diameter through seed yield/plant (0.34). Furthermore, high estimates of genotypic and phenotypic positive indirect effects were observed by head diameter through each of days to $50 \%$ flowering and 100-seed weight and by 100 -seed weight via seed weight/plant. However, the maximum negative indirect effects on oil yield were obtained from head diameter via plant height $(-0.24)$ and days to $50 \%$ flowering through steam diameter $(-0.23)$ at genotypic and phenotypic levels, respectively. Regarding location 3, path analysis proved that plant height followed by seed yield/plant via head diameter had the highest genotypic positive indirect effects on oil yield (0.29 and 0.25). On the other side, each of days to $50 \%$ flowering followed by seed yield/plant through head diameter gave the maximum phenotypic positive indirect effects on oil yield (0.30 and 0.29). Furthermore, high estimates of genotypic and phenotypic positive indirect effects were observed by days to $50 \%$ flowering through head diameter, steam diameter via 100 -seed weight and head diameter via 100-seed weight and each of 100-seed weight and steam diameter through head diameter. However, the highest negative indirect effects on oil yield were recorded from head diameter via seed yield/plant $(-0.39)$ and from plant height via head diameter $(-0.42)$ at genotypic and phenotypic levels, respectively. The remainder indirect effects were very small and little importance. An overall view on the results of path analysis, it is proved that the traits, i.e. days to $50 \%$ flowering, head diameter, steam diameter, 100 seed weight and seed yield/plant are considered as direct and indirect selection criteria for oil yield in sunflower. Similar results were reported by Punnia \& Gill (1994), El-Hosary et al. (1999), Hladni et al. (2010) and Hassan et al. (2013) who confirmed the importance of path analysis when deciding upon selection criteria using yield components.

The relative importance (RI \%) according to genotypic and phenotypic path analysis are presented in Table 7. It is evident that the most oil yield variation (genotypic and phenotypic) was explained by the direct effects for $50 \%$ flowering (28.10 and 33.14) followed by plant height (13.21 and 2.22). For location 2 it is evident that the most oil yield variation (genotypic and phenotypic) was explained by the direct effects for weight 100 seeds (19.43 and 
6.39) followed by plant height (4.81 and 1.39), 50\% flowering (4.40 and 1.28) and head diameter (1.94 and 2.25). The data of relative importance (RI \%) also revealed that for location 3 the most oil yield variation (genotypic and phenotypic) was explained by the direct effects for seed yield/plant (17.43 and 8.87) followed by weight 100 seeds (16.01 and 5.65).

TABLE 7. The relative importance (RI \%) of six predictor characters on oil yield (kg/fed) at genotypic and phenotypic levels evaluated individually under three locations over the two seasons

\begin{tabular}{|c|c|c|c|c|c|c|c|}
\hline \multirow{2}{*}{\multicolumn{2}{|c|}{ Characters }} & \multicolumn{2}{|c|}{ Shandaweel } & \multicolumn{2}{|c|}{ Al-Araish } & \multicolumn{2}{|c|}{ El-ewynat east } \\
\hline & & G & $\mathbf{P h}$ & G & $\mathbf{P h}$ & G & $\mathbf{P h}$ \\
\hline \multicolumn{2}{|c|}{ DF } & 28.10 & 33.14 & 4.40 & 1.28 & 0.32 & $\mathbf{3 . 3 0}$ \\
\hline \multicolumn{2}{|l|}{$\mathrm{PH}$} & 13.21 & 2.22 & 4.81 & 1.39 & 0.67 & 1.97 \\
\hline \multicolumn{2}{|l|}{ H D } & 9.33 & 0.04 & 1.94 & 2.25 & 6.26 & 12.50 \\
\hline \multicolumn{2}{|l|}{ H D } & 0.14 & 4.44 & 2.23 & 0.48 & 0.05 & 1.08 \\
\hline \multicolumn{2}{|l|}{ 100-SW } & 0.60 & 0.58 & 19.43 & 6.39 & 16.01 & 5.65 \\
\hline \multicolumn{2}{|l|}{$\mathrm{SY} / \mathrm{P}$} & 1.56 & 2.85 & 0.09 & 13.55 & 17.43 & 8.87 \\
\hline $\mathrm{X} 1$ & $\mathrm{X} 2$ & 13.84 & 7.19 & 3.42 & 0.77 & 0.27 & 1.41 \\
\hline $\mathrm{X} 1$ & $\mathrm{X} 3$ & 6.94 & 0.60 & 3.71 & 1.83 & 11.45 & 6.33 \\
\hline $\mathrm{X} 1$ & $\mathrm{X} 4$ & 1.26 & 10.72 & 2.30 & 0.53 & 0.10 & 1.41 \\
\hline $\mathrm{X} 1$ & $\mathrm{X} 5$ & 1.99 & 2.90 & 4.14 & 1.67 & 1.54 & 2.25 \\
\hline $\mathrm{X} 1$ & X6 & 2.68 & 5.15 & 0.12 & 0.71 & 0.05 & 0.21 \\
\hline $\mathrm{X} 2$ & $\mathrm{X} 3$ & 2.95 & 0.03 & 4.75 & 2.92 & 2.79 & 6.90 \\
\hline $\mathrm{X} 2$ & $\mathrm{X} 4$ & 1.72 & 4.63 & 2.98 & 0.30 & 0.05 & 0.54 \\
\hline $\mathrm{X} 2$ & $\mathrm{X} 5$ & 0.17 & 0.13 & 4.20 & 1.48 & 0.21 & 0.96 \\
\hline $\mathrm{X} 2$ & X6 & 1.77 & 0.51 & 0.71 & 6.41 & 2.61 & 3.08 \\
\hline X3 & $\mathrm{X} 4$ & 0.07 & 0.03 & 1.50 & 0.37 & 0.26 & 1.94 \\
\hline X3 & $\mathrm{X} 5$ & 0.03 & 0.01 & 3.53 & 2.23 & 5.17 & 5.90 \\
\hline X3 & X6 & 2.20 & 0.21 & 0.51 & 8.09 & 11.30 & 10.32 \\
\hline X4 & $\mathrm{X} 5$ & 0.14 & 0.99 & 4.45 & 0.94 & 0.58 & 1.72 \\
\hline X4 & X6 & 0.22 & 2.35 & 0.19 & 0.02 & 0.03 & 0.09 \\
\hline $\mathrm{X} 5$ & X6 & 0.34 & 0.54 & 1.10 & 6.85 & 16.49 & 5.93 \\
\hline Direct + & irect & 89.23 & 79.23 & 70.51 & 60.02 & 83.63 & 82.33 \\
\hline Residua & & 10.77 & 20.77 & 29.49 & 39.80 & 16.37 & 17.67 \\
\hline Total & & 100 & 100 & 100 & 100 & 100 & 100 \\
\hline
\end{tabular}


Also, the great genotypic and phenotypic components of joint effects were expressed by $50 \%$ flowering on oil yield via its association with plant height (13.84 and 7.19), stem diameter (1.26 and 10.72) and seed yield/plant (2.68 and $5.15)$ and by plant height via stem diameter (1.72 and 4.63) in location 1. For location 2 the great genotypic and phenotypic components of joint effects were expressed by $50 \%$ flowering on oil yield via its association with head diameter (3.71 and 1.83) and weight 100 seeds (4.14 and 1.67), plant height via head diameter (4.75 and 2.92) and weight 100 seeds (4.20 and 1.48), head diameter via weight 100 seeds (3.53 and 2.23) and weight 100 seeds via seed yield/plant (1.10 and 6.85). Moreover, in location 3 great genotypic and phenotypic components of joint effects were expressed by $50 \%$ flowering on oil yield via its association with head diameter (11.45 and 6.33), and weight 100 seeds (1.54 and $2.25)$, plant height via head diameter (2.79 and 6.90) and seed yield/plant (2.61 and 3.08), head diameter via weight 100 seeds (5.17 and 5.90) and seed yield/plant (11.30 and 10.32), and weight 100 seeds via seed yield/plant (16.49 and 5.93).

Negligible values of relative importance were observed for the other direct and indirect influences. Totally, the studied six characters explained $(89.23 \%$ and $79.23 \%),(70.51 \%$ and $60.02 \%)$ and $(83.63 \%$ and $82.33 \%)$ in the three locations, respectively of oil yield variation at the genotypic and phenotypic levels, respectively. In accordance, the residual part may be attributed to unknown variation (random error), committing of errors during measuring the studied characters and/or some other traits that were not incorporated in the present study.

In conclusion, among the studied characters days to 50\% flowering, weight 100 seeds and seed yield/plant were the most reliable oil yield components as selection criteria in sunflower breeding programs.

\section{References}

Abdou, S.M.M., Abd El-Latif, K.M. , Farrag, R. M.F. and Yousef, K.M.R. (2011) Response of sunflower yield and water relations to sowing dates and irrigation scheduling under middle Egypt condition. Adv. Appl. Sci. Res. 2(3), 141-150.

Allam, A.Y., El-Nagar, G.R. and Galal, A. H. (2003) Response of two sunflower hybrids to planting dates and densities. Acta Agro. Hung. 51(1), 25-35.

AOAC (1980) "Official Method of Analysis" of the Association of Official Agriculture Chemists. $13^{\text {th }}$ ed., AOAC, Washington, DC., USA.

Atia, A. A. M. (2007) PATHCA: A BASIC program for estimating phenotypic, genotypic and environmental path coefficient, an application on maize. The $42^{\text {nd }}$ Annual Conf. of Statistics, Computer Sciences and Operation Research, Institute of Statistical Studies and Research. Cairo Univ. pp.76-87, Egypt, 2-5 December.

Brim, C. A., Johnson, H. W. and Cockerham, C.C. (1959) Multiple selection criteria in soybeans. Crop Sci. 1,187-190.

Egypt. J. Agron . 37, No. 2 (2015) 
Dewey, D.R. and Lu, K.H. (1959) A correlation and path coefficient analysis of components of crested wheat grass seed production. Agron. J. 51, 515-518.

El-Hosary, A., El-Ahmar, B. and El-Kasaby, A.E. (1999) Assocition studies in sunflower. Helia, 22 (special issue), 561-567.

Farhatullah, F.E.A. and Ifikhar, H. K. (2006) Path analysis of the coefficients of sunflower (Helianthus annuus L.) hybrids. International Journal of Agriculture \& Biology, 8 (5), 621 - 625.

Fick, G. N., Zimmer, D. C. and Zimmerman, D. C. (1974) Correlation of seed oil content in sunflower with other plant and seed Characteristics. Crop Sci. 14, 755757.

Fick, G.N. and Miller, J. F. (1997) Sunflower breeding. In "Sunflower Technology and Production", E.E. Schneiter.(Ed.) SA, CSSA, SSSA. Madison, Wisconsin, USA.

Green, V.E. (1980) Correlation and path analysis of the components of yield in sunflower cultivars: (Helianthus annuus L.). In: Proc. of the $9^{\text {th }}$ Int. Sunflower Conf., pp: 12-21. June, 8-13, 1980. Terremolinos-Malage, Spain.

Habib, H., Mehdi, S.S., Anjum, M. A. and Ahmed, R. (2007) Genetic association and path analysis for oil yield in sunflower (Helianthus annuus L.). International J. Agric. Biol. 2, 259-1.

Hassan, S.M., Iqbal, M.S., Rabbani, G., Alddin, N., Shabbir, G., Riaz, M. and Noorka, I. R. (2013) Correlation and path analysis for yield and yield components in sunflower (Helianthus annuus L.). African J. Biotech. 12, 1968-1971.

Hlandi, N., Jocic, S., Miklic, V., Mijic, A., Saftic, D., Pankovic, D. and Skoric, D. (2010) Effect of morphological and physiological traits on seed yield and oil content in sunflower. Helia, 33, 101-116.

Humera, R., Muhammad, H.N.T. and Hafeez, A. (2014) Genetic variability in sunflower (Helianthus annuus L.) for achene yield and morphological characters . I.J.S.N., 5 (4), 669-676.

Johnson, H. W., Robinson, H. F. and Comstock, R. E. (1955) Estimation of genetic and environmental variability in soybean. Agron. J. 47, 314-318.

Kang, M. S. (1994) “Applied Quantitative Genetics”. Kang publ. Baton Rouge, LA, USA.

Kang, Sh. A. and Ahmed, H. M. (2014) Genetic variability and path coefficient analysis for yield related traits in Helianthus annus. Journal of Biology, Agriculture and Healthcare, 4 (11), 54-57.

Labana, K. S., Chaurasis, B. D. and Singh, B. (1980) Genetic variability and inter character associations in the mutants of Indian mustard Indian. G. Agri. Sci. 50, 803-806. 
Levene, H. (1960) Robust tests for equality of variances. In Ingram Olkin, Harold Hotel ling, Italia, Stanford, Univ. press, pp. 278- 292.

Marinkovic, R. (1992) Path-coefficient analysis of some yield components of sunflower. Euphytic, 60, 201-205.

Punnia, M. S. and Gill, H. S. (1994) Correlations and path-coefficient analysis for seed yield traits in sunflower (Helianthus annuus L.). Helia, 17,7-12.

Sharief, A. E. (1998) Productivity of some introduced sunflower cultivars as affected by planting date and plant population distance. Zagazig J. Agric. Res. 25, 895-909.

Skoric, D. (1974) Correlation among the most important characters of sunflower in $F_{1}$ generation. In: Proc. $6^{\text {th }}$ Intl. Sunflower Conf., Bucharest, Romania, 22-24 July. Intl. Sunflower Assoc., Paris, France I: pp. 283-289.

Snedecor, G. W. and Cochran, W. G. (1989) "Statistical Methods". $8^{\text {th }}$ ed., Iowa State Univ. Press, Ames, Iowa, USA.

Vega, A. J., Hall, A. J. and Vega, A. J. (2002) Effects of planting date, genotype and their interactions on sunflower yield. II. Components of oil yield. Crop Sci. 42, 12021210 .

Vranceanu, A. V. (2000) Floarea- soarelui hibrida. Editura Ceres. Bucharest, Romania.

Wright, S. (1921) Correlation and causation. J. Agric. Res. 20, 557-585.

(Received 10/6/2015; accepted $3 / 8 / 2015$ ) 


\section{تقدير الاختلافات الوراثية و الارتباط و معامل المرور فى دوار

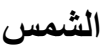

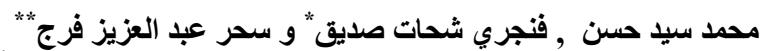

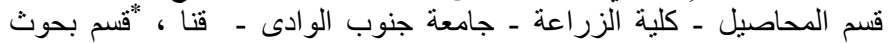

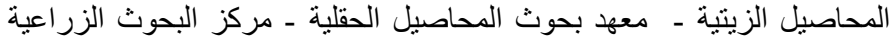

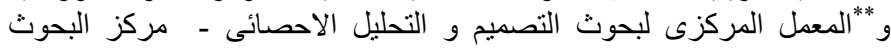

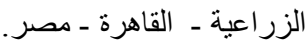

تم تقييم 12 نركيب ور اثى من دوار الثمس خلال الموسم الصيفى لعامى 2013

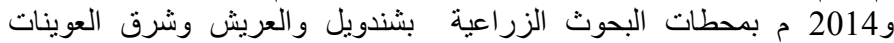
باستخدام تصميم القطاعات كاملة العشو ائية فى ثلاثة مكررات

استهدف العمل البحثى در اسة التباين عبر تقدير معاملات الاختلاف المظهرية

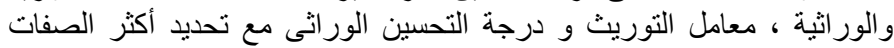

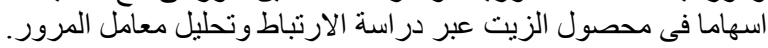

$$
\text { وتتلخص أهم النتائج المتحصل عليها فيما يلى: }
$$

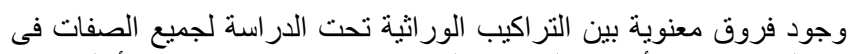

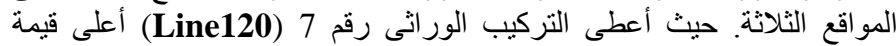

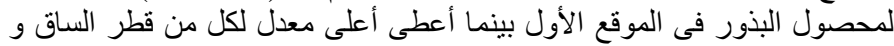

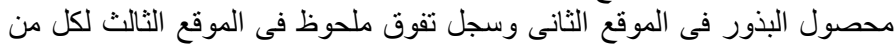

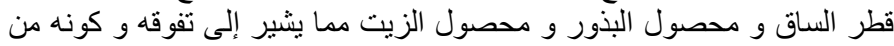

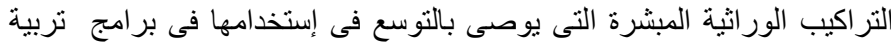

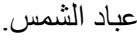

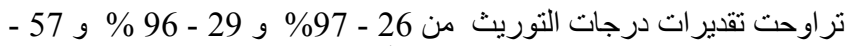

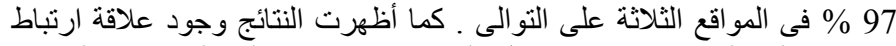

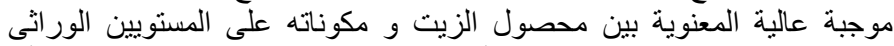

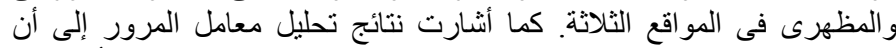

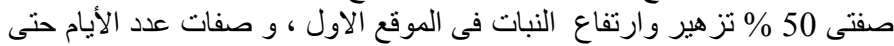

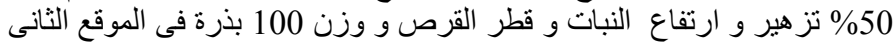

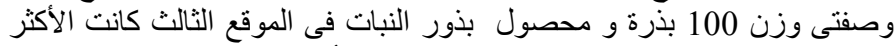

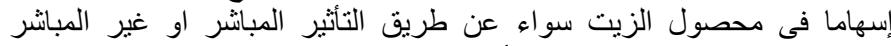

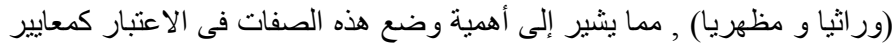

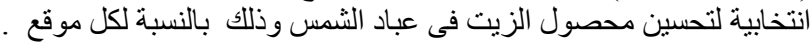

